\title{
Effect of an hydrophobic layer on a universal adhesive
}

\author{
Efeito de uma camada hidrofóbica sobre um adesivo universal
}

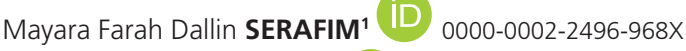 \\ Adriana Mara Araújo LEAL ${ }^{1}$ ID 0000-0002-7006-366X \\ José BAUER ${ }^{2}$ iD 0000-0003-3761-0331 \\ Isabella Azevedo GOMES ${ }^{1}$ iD 0000-0001-9554-3785 \\ Karina Gama Kato CARNEIRO' ${ }^{1}$ iD 0000-0001-8066-4023
}

\begin{abstract}
Objective: evaluate bond strength of a universal adhesive, associated to an extra hydrophobic sealing layer, and compare after three and six months immersed in distilled water. Methods: After ethical approval of the CEP / HUUFMA, 12 human third molars $(n=6)$ were extracted, which were divided into two groups: SB - control group - selfetching; and SBHidrof - selfetching group associated to the hydrophobic layer (Adhesive layer, 3m ESPE). After incremental restoration with composite resin (Opalis, FGM), the teeth were sliced to obtain specimens ( $1 \mathrm{~mm} 2$ ) and then submitted to the universal test machine (INSTRON $1 \mathrm{~mm} / \mathrm{min}$.), immediate and after three and six months. The data were submitted to normality (Shapiro Wilk), and comparative Analysis of variance (two ways: technique and time) and Tukey ( $p<0.05)$. Results Immediate values showed no statistically significant difference $(p>0.05)$, but after three and six months of immersion of the specimens, in distilled water, bond strength values were maintained in the group that received the hydrophobic layer $(p<0.05)$. Conclusion: It was observed that, by incorporating a hydrophobic layer on a universal adhesive system, it was possible to preserve dentin adhesion.
\end{abstract}

Indexing terms: Adhesive. Dentistry. Tensile strength.

\section{RESUMO}

Objetivo: Avaliar a de resistência de união da interface adesiva associada a uma camada hidrofóbica extra de selamento, e comparar após três e seis meses de armazenamento em água destilada. Métodos: Foram utilizados 12 terceiros molares humanos extraídos hígidos $(n=6)$, que foram divididos em dois grupos, sendo grupo SB - controle - autocondicionante; e grupo SBHidrof - autocondicionante associado à camada hidrofóbica (Adhesive layer, 3 m ESPE). Após restauração incremental com resina composta (Opalis, FGM), os dentes foram fatiados para obtenção de espécimes (1 $\mathrm{mm} 2$ ) e em seguida, submetidos à máquina de ensaio universal (INSTRON $1 \mathrm{~mm} / \mathrm{min}$.) imediato e após três e seis meses. Os dados obtidos foram submetidos à normalidade (Shapiro Wilk), e análise comparativa ANOVA (dois fatores: técnica e tempo) e Tukey $(p<0,05)$. Resultados: Nos valores imediatos não houve diferença estatisticamente significante ( $p>0,05)$, porém após três e seis meses de imersão dos espécimes, em água destilada, foi observado manutenção dos valores de resistência de união no grupo que recebeu a camada hidrofóbica $(p<0,05)$. Conclusão: Ao incorporar uma camada hidrofóbica sobre um sistema adesivo universal, foi possível preservar a longevidade da adesão dentinária.

Termos de Indexação: Adesivos. Odontologia. Resistência à tração.

\footnotetext{
1 Universidade Ceuma, Curso de Odontologia. Rua Josué Montello, 1, Renascença II, 65075-120, São Luís, MA, Brasil. Correspondência para / Correspondence to: KGK CARNEIRO. E-mail: <carneirokarina@hotmail.com>.

2 Universidade Federal do Maranhão, Programa de Pós-graduação em Odontologia, São Luís, MA, Brasil.

$\boldsymbol{\nabla} \mathbf{v} \boldsymbol{v}$

Como citar estar artigo / How to cite this article

Dal'ling MF, Leal AMA, Bauer J, Carneiro KGK. Effect of an hydrophobic layer on a universal adhesive. RGO, Rev Gaúch Odontol. 2018;66(4):339-344. http://dx.doi.org/10.1590/1981-863720180004000073500
}

$\checkmark v$ 


\section{INTRODUCTION}

Improvements in adhesive restorative materials, associated with their practicality, aesthetics and absence of the need to remove healthy dental tissue, have contributed to professionals' and patients' preference for light-curing systems [1]. The desired sealing of dentin substrate achieved with the use of an adhesive system, and operative procedures that minimize the factors that make this technique sensitive $[1,2]$, have been decisive in preventing the occurrence of situations capable of making it necessary to replace adhesive restorations [2].

Recently, systems known as universal adhesives were introduced [3]. These systems, characterized as being composed of acidic monomers with low etching aggressiveness, are presented in a single bottle and with the proposal of incorporating the smear layer on the dentin substrate into the hybrid layer [3]. The purpose of this bonding system is to eliminate acid etching of dentin; and previous conditioning of only more mineralized substrate such as enamel is suggested, thereby allowing the optimization of clinical time [4].

The hydrophilic characteristics of the monomers of universal single-bottle adhesive systems may represent undesirable water permeability and compromise durability of the bond [5-7]. The acidic monomers present in the mixture make it hydrophilic, and in the long term, the effects of the resultant water sorption, compromise the mechanical characteristics of the material [5]. This is due to the affinity of the monomer for forming hydrogen bonds with the hydrophilic portion of the acidic groups, and consequently changes the formation of the polymer chain [5].

In an attempt to maintain the quality of the adhesive layer, some studies have proposed a change in the way of applying the bonding system, such as the application of an extra hydrophobic adhesive sealing layer [2-4]. This maneuver is reported in the literature as being favorable to the quality of the bond interface [3]. Studies [2-4] have shown bond strength [3], longevity in clinical behavior [4], degree of conversion [2] and nanoinfiltration [3] results with higher values for the groups that received a layer of hydrophobic sealing monomers.

Although this proposal involves an additional step that causes an increase in clinical time, it may protect the integrity of the adhesive interface over time. Other proposals, such as the use of sonic devices [8]; application of multiple layers [9] and use of bioactive substances $[10,11]$; are found in the literature, but their ability to maintain bond strength (BS) longevity has not been conclusively proved.

Since there is no knowledge in the literature about the efficacy of changing the modes of application of the universal adhesive system, the aim of the present research was to perform an in vitro evaluation of the effect of incorporating an extra hydrophobic sealing layer into the bond interface, on the bond strength of the universal adhesive system, by means of testing the bond strength immediately after the sample preparation, and after storage in distilled water for time intervals of three and six months.

\section{METHODS}

The sample calculation for Analysis of Variance and Test Power of $0.8(80 \%)$ obtained the number of samples $n=6$. Thus, after approval of the CEP / UNICEUMA (37550314.5.0000.5086), we used 12 third human molars that had recently been extracted and donated after spontaneous consent and signature of the donation term. The specimens were randomly divided into two experimental groups, SB Group: control-self-conditioning (Single Bond Universal, 3M / ESPE, St. Paul, MN, USA) and SBHidrof Group: control associated with the hydrophobic layer (Adhesive, 3M / ESPE, St. Paul, MN, USA) (table 1). The teeth were stored in $0.1 \%$ Thymol solution until used in this study.

The enamel on the occlusal surface of the teeth was removed by progressive wear with silicon carbide abrasive paper grit 180, under constant irrigation with water until a completely enamel-free dentin surface was obtained. Subsequently the surface was abraded with silicon carbide abrasive paper grit 600 for $60 \mathrm{~s}$ to standardize the smear layer.

The adhesive system was applied actively in accordance with the manufacturer's instructions (table 1), followed by a gentle jet of air at a distance of $20 \mathrm{~cm}$, for 10 seconds, and light activated for 10 seconds with an Optilux 501 (Demetron, Danbury, USA) appliance, with an intensity of approximately $600 \mathrm{~mW} / \mathrm{mm}^{2}$.

After the adhesive procedure, Opalis composite resin (FGM, Joinvile, Santa Catarina, Brazil) was applied in 
Table 1. Composition and protocol of application of the adhesive systems used in all groups.

\begin{tabular}{|c|c|c|}
\hline Groups & Composition ${ }^{*}$ & Bond strength protocol \\
\hline $\begin{array}{l}\text {-SB: } \\
\text { Single Bond Universal } \\
{[3 \mathrm{M} / \mathrm{ESPE}]}\end{array}$ & $\begin{array}{l}\text { - Universal Adhesive: MDP phosphate monomer, Dimethacrylate, } \\
\text { HEMA, filler, ethanol, water, initiators, silane }\end{array}$ & $\begin{array}{l}\text {-Apply with a microbrush and rub in for } 20 \mathrm{~s} \\
\text {-Gentle stream of air about } 5 \mathrm{~s} \\
\text {-Light-cure for } 10 \mathrm{~s}\end{array}$ \\
\hline $\begin{array}{l}\text {-SBHidrof: } \\
\text { 1-Single Bond Universal } \\
\text { 2-Hydrofobic layer (Step 2-Scotchbond } \\
\text { multipurpose) } \\
\text { [3M/ESPE] }\end{array}$ & $\begin{array}{l}\text { 1-Universal Adhesive: MDP phosphate monomer, } \\
\text { Dimethacrylate, HEMA, filler, ethanol, water, initiators, silane }\end{array}$ & $\begin{array}{l}\text { 1-Apply with a microbrush and rub in for } 20 \mathrm{~s} \\
\text {-Gentle stream of air about } 5 \mathrm{~s} \\
\text {-Light-cure for } 10 \mathrm{~s} \\
\text { 2- Apply with a microbrush } \\
\text {-Gentle stream of air about } 5 \mathrm{~s} \\
\text {-Light-cure for } 10 \mathrm{~s}\end{array}$ \\
\hline
\end{tabular}

Note: *manufacturer instructions.

Table 2. Mean and standard deviation of bond strength: immediate, three and six months of all groups.

\begin{tabular}{|c|c|c|c|}
\hline Groups & 24 hours & 3 months & 6 months \\
\hline
\end{tabular}

Note: ${ }^{*}$ Different horizontal letters mean statistically significant different $(p<0.05)$.

two increments ( $2 \mathrm{~mm}$ each), forming a layer approximately $4 \mathrm{~mm}$ high. Each resin increment was light activated for $40 \mathrm{~s}$ with an Optilux 501 light polymerizer (Demetron, Danburry, USA). The experimental units were then stored in distilled water at $37^{\circ} \mathrm{C}$ for $24 \mathrm{~h}$.

Each experimental unit was attached to a cutting machine device (ISOMET 1000 - Buheler, Illinois, USA) with sticky wax, with the joint interface perpendicular to the cutting disc. Two sequences of longitudinal and perpendicular cuts were made to obtain stick-shaped specimens with a rectangular section area of approximately $1.0 \mathrm{~mm} 2$. The number of sticks prematurely lost during specimen preparation was noted (table 2).

The sticks of each tooth were then randomly divided into three groups to be tested at different times: immediately after their preparation, after three months of their storage in distilled water, and after six months in distilled water.

Each specimen, in its respective period of analysis, was fixed with cyanoacrylate gel glue (Super Bonder, Loctite, São Paulo, Brazil) to a Geraldeli testing jig. This jig was inserted into a universal test machine (INSTRON, São Paulo, Brazil) so that the tensile stresses would occur perpendicular to the bond interface. The machine was operated at a speed of $0.5 \mathrm{~mm} / \mathrm{min}$. The fractured specimens were analyzed under a microscope (KOZO, Japan) and classified according to the following fracture patterns: 1) dentin cohesive; 2) cohesive composite resin; 3) adhesive / mixed at the interface (figure 1). The data were tabulated, and after the normality test, two-way Analysis of Variance and Tukey tests were performed.

\section{RESULTS}

After proof of normality by means of Shapiro Wilk ( $p>0.05)$, two-way ANOVA (factor: technique) and Tukey tests showed no statistical difference for the immediate values; the group with incorporation of hydrophobic sealing layer was observed to obtain a similar result to that of the control group (table 2).

When we isolated the hydrophobic layer group, (after testing normality by means of Shapiro Wilk ( $p>0.05$ ), two-way (time and hydrophobic layer) ANOVA and Tukey test were performed), we observed that the bond strength values were maintained in the group that received the hydrophobic layer application after the universal adhesive $(P>0.05)$, thereby preserving the longevity of the interface, while the control group presented a lower value than the initial one (table 2). 


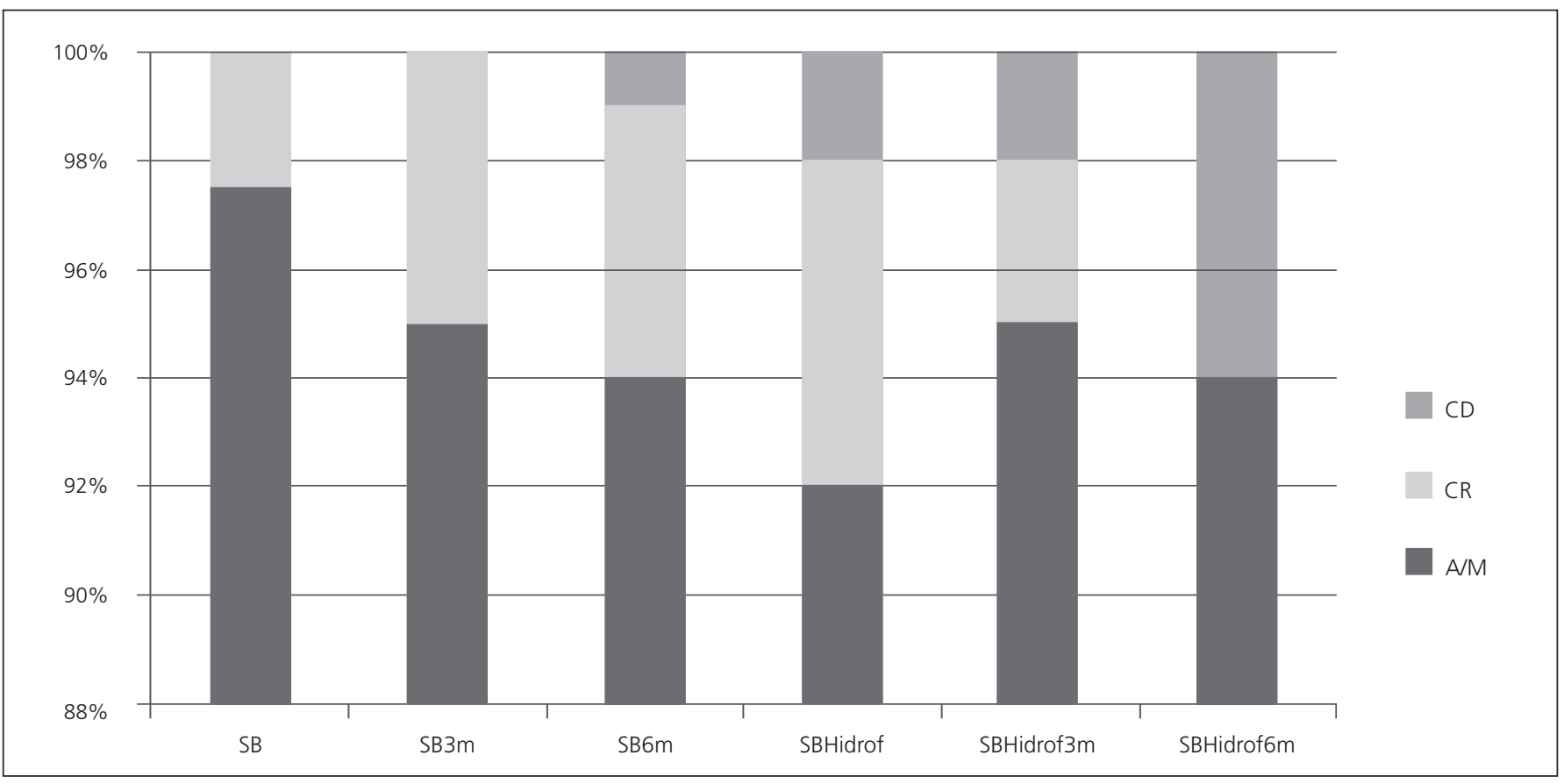

Figure 1. Chart means fracture pattern, according to the specimens evaluated (\%).

In addition, in all the groups evaluated, the Adhesive / Mixed fracture pattern (figure 1) was predominantly observed, which characterized a pattern close to that of the bond strength observed, that is; to approximately the real value that the adhesive system resisted.

\section{DISCUSSION}

In addition to the self-etch adhesives presenting easier application protocols than the conventional types, they are less sensitive to the adhesive technique [12]. This is because there is no discrepancy between the acid etching and resin monomer infiltration into the substrate in these systems, which reduces the possibility of having unprotected collagen that is susceptible to degradation $[12,13]$.

Moreover, in the immediate bond strength tests, the universal systems presented satisfactory performance on both wet or dry substrates, which reduces this sensitivity to the application mode [12]. The components of an aqueous solution of acidic monomers present hydrophilic characteristics; that is, they require the presence of water to promote ionization and to act on the substrates, which could compromise the bond interface $[13,14]$.
The hybrid layer observed in self-etch adhesive systems is porous and allows the passage of fluids that are consequently capable of causing the accumulation of liquid on the surface of the adhesive layer, and leading to reduction in bond strength values $[14,15]$. This justifies the present research, since the bond strength test results after three and six months were lower than the immediate values in the SB group, and thus confirm impairment of the adhesive interface in the control group.

However, the same did not occur in the group that received the application of an extra hydrophobic layer. The same bond strength found in the immediate tests was shown to be preserved after three and six months, but the application of an additional layer of hydrophobic resin on the Universal Single Bond was observed to lead to maintain bond strength.

When the hydrophobic layer was applied, the concentration of hydrophobic monomers on the surface increased [14], in addition to increasing the thickness of the adhesive, making it more uniform and reducing the consequences of water and solvent accumulation [3].

These results were justified by the fact that to create a self-etch system, acidic, hydrophilic and hydrophobic monomers were mixed in a single bottle with 
organic solvents and water, which gave this system a highly hydrophilic characteristic [12].

The accumulation of water present in the hybrid layer, caused by the residual water resulting from the incomplete evaporation of the adhesive joining with the water present in the dentinal tubules, thus created channels filled with water inside the adhesive [3].

The hydrophobic layer enhanced the resin coating on the surface, and did not interfere in the light activation of the resin; it also causes a barrier to the uptake of fluids over time. Since it avoided the hydrogen bonding, it consequently prevented both plasticization of the polymer and reduction in the bond durability [4].

Although there increasing demand for simplified adhesives, implementation of the protocol is more susceptible to water accumulation, so that there is loss of bond efficacy [16], making it necessary to improve the bond durability. Thus the proposal to use a hydrophobic adhesive together with the single-bottle self-etching adhesive system is important for the purpose of preserving the bond strength of the system.

Therefore, our results showed that an extra layer of sealing not only increased the thickness of the adhesive layer, but also intensified the hydrophobic characteristic and proposed to reduce the permeability of fluids through the bond interface. In addition, it allowed a lower concentration of solvents and unpolymerized monomers, and thus enabled a greater area of contact between restorative material and dentin, which produced a higher degree of conversion and consequent improvement in the mechanical properties $[4,8]$.

Although an extra step was added to the selfetching adhesive application protocol, this procedure was less sensitive to the probability of failure than the step of conditioning, washing and removing excess water. Moreover, it was shown to be promising for preserving the bond strength quality over time.

\section{CONCLUSION}

The incorporation of an extra hydrophobic sealing layer into a universal adhesive system did not improve the $\mathrm{RU}$ values in the immediate tests; however, it proved to be a solution favorable to preserving the longevity of the dentin bond.
Collaborators

MFD SERAFIM Acted on the practical execution of the mechanical tests (bond strength and initial manuscript). AMA LEAL: Acted in the laboratory supervision of the mechanical tests in aid to the student. J BAUER: Idealized the initial project and assisted in the statistical analysis. IA GOMES: Performed the revision of the writing process of the manuscript in front of the orientation of the student. KGK CARNEIRO: Project coordinator, responsible for writing and final review of all stages.

\section{REFERENCES}

1. Perdigão J, Geraldeli S, Hodges JS. Total-etch versus self-etch adhesive effect of postoperative sensitivity. J Am Dent Assoc. 2003;134(12):1621-29. https://doi.org/10.14219/jada.archive. 2003.0109

2. Munõz MA, Sezinando A, Martinez IL, Szezs AL, Reis A, Louguercio $A D$, et al. Influence of a hydrofobic resin coating on the bonding efficacy of three universal adhesives. J Dent. 2014;42(5:595-602. https://doi.org/10.1016/j.jdent.2014.01. 013

3. Sezinando A, Martinez IL, Munõz MA, Reis A, Louguercio $A D$. Perdigão J. Influence of a hydrofobic resin coating on the immediate and 6-month dentin bonding of three universal adhesives. Dent Mater. 2015; 31(10):e236-246. doi:10.1016/j.dental.2015.07.002

4. Reis A, Leite TM, Matte K, Michels R, Amaral RC, Geraldeli $S$, et al. Improving clinical retention of one-step self-etching adhesive systems with an additional hydrophobic adhesive layer. J Am Dent Assoc. 2009;140(7):877-85. https://doi. org/10.14219/jada.archive.2009.0281

5. Yiu CKY, King NM, Pashley DH, Suh BI, Carvalho RM, Carrilho $M R O$. Effect of resin hydrophilicity and water storage on resin strength. Biomater. 2004;25(26):5789-96. https://doi. org/10.1016/j.biomaterials.2004.01.026

6. Malacarne J, Carvalho RM, De goes MF, Svizero N, Pashley $\mathrm{DH}$, Tay FR, et al. Water sorption/solubility of dental ahesive resins. Dent Mater. 2006; 22(10):973-980. https://doi.org/ doi:10.1016./j.dental

7. Manso AP, Bedran-Russo AK, Suh B, Pashley DH, Carvalho RM. Mechanical stability of adhesives under water storage. Dent Mater. 2005;21(3):232-41. https://doi.org/10.1016/j.dental. 2008.12.006

8. Mena-Serrano A, Costa TR, Patzlaff RT, Loguercio AD, Reis A. Effect of sonic application mode on the resin-dentin bond strength and dentin permeability of self-etching systems. J Adhes Dent. 2014;16(5):435-40. https://doi.org/10.3290/j. jad.a32810

9. Reis A, Albuquerque M, Pegoraro M, Mattei G, Bauer JR, Grande $\mathrm{RH}$, et al. Can the durability of one-step self-etch adhesives be improved by double application or by an extra layer of hydrophobic resin? J of Dent. 2008;36(5):309-15. https://doi.org/10.1016/j.jdent.2008.01.018 
10. Hashimoto M, Lijima M, Nagano F, Ohno H, Endo K. Effect of monomer composition on crystal growth by resin containing bioglass. J Biomed Mat Res B: Appl Biomater. 2010;94:(1)127-33. https://doi.org/10.1002/jbm.b.31632

11. Carneiro KK, Meier MM, dos Santos CC, Maciel AP, Carvalho $\mathrm{CN}$, Bauer J. Adhesives doped with bioactive niobophosphate micro-filler: degree of conversion and microtensile bond strength. Braz Dent J. 2016;27(6):706-11. https://doi.org/10. 1590/0103-6440201601110

12. Muñoz MA, Luque I, Hass $V$, Reis $A$, Loguercio AD, Bombarda $\mathrm{NHC}$. Immediate bonding properties of universal adhesives to dentine. J Dent. 2013;41(5):404-11. https://doi.org/10.1016/j. jdent.2013.03.001.

13. Reis A, Albuquerque M, Pegoraro M, Mattei G, Bauer JR, Grande $\mathrm{RH}$, et al. Can the durability of one-step self-etch adhesives be improved by double application or by an extra layer of hydrophobic resin? J Dent. 2008;36(5):309-15. https:// doi.org/doi:10.1016/j.jdent.2008.01.018
14. Bortolatto JF, Takatsui F, Oliveira Junior OB, Andrade MF, Kuga MC, Campos EA. Effect of additional hydrofobic layer on the microtensile bond strenght of all-in-one adhesive systems. Rev Odontol UNESP. 2011;40(3):113-117.

15. De Andrade e Silva SM, Carrilho MR, Marquezini Junior L, Garcia FC, Manso AP, Alves MC, et al. Effect of an additional hydrophilic versus hydrophobic coat on the quality of dentinal sealing provided by two-step etch-and-rinse adhesives. J Appl Oral Sci. 2009;17(3):184-9. https://doi.org/10.1590/S1678-77 572009000300010

16. Silva e Souza Junior MH, Carneiro KGK, Lobato MF, Silva e Souza PAR, De Góes MF. Adhesive systems: importante aspects related to their composition and clinical use. J Appl Oral Sci. 2010;18(3):2017-14. https://doi.org/10.1590/S16 78-77572010000300002

Received on: 29/11/2017 Final version resubmitted on: 20/3/2018

Approved on: 19/5/2018 